\title{
Manufacturing Hiring Trends: Employers Seeking More Diverse Skills
}

\author{
Daniel W. Sullivan, Ashland University, USA
}

\begin{abstract}
According to the National Association of Manufacturers (NAM), 32\% of American manufactures reported that even during the height of the recession, they had unfilled job openings. The reason cited for this phenomenon was that American manufacturers were unable to find workers with the skills they required. The inability to close the gap between the managerial skills American manufacturers want and the skills available in the workforce continues to hinder the hiring process. In an effort to understand the disconnect, this study was conducted among manufacturers with facilities located in Ohio, Indiana, and Michigan areas to determine the skills most sought after by manufacturers as they attempt to hire recent college graduates. The results revealed a shift away from the traditional skill focus of engineering curriculums toward a more rounded skill set - one relying heavily on a host of people skills and a sophisticated understanding of the cross functional relationships that exist between traditional disciplines. The study also revealed that manufactures are placing an increased emphasis on outside certifications as a way to reduce expensive in-house training costs. Finally, employers are looking to institutions of higher learning as leaders in their effort to provide the skills graduates need to succeed in manufacturing.
\end{abstract}

Keywords: Manufacturing Hiring Trends; Manufacturing Skills; Manufacturing Curriculums; Diverse Skills

\section{INTRODUCTION}

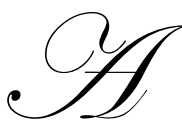

ccording to the National Association of Manufacturers (NAM), 32\% of American manufactures reported that even during the height of the recession, they had unfilled job openings. The reason cited for this phenomenon was that American manufacturers were unable to find workers with the skills they required (Olsen, 2011; Handler \& Healey, 2009). The inability to close the gap between the skills American manufacturers want and the skills available in the workforce continues to be an issue of concern for government officials (Olson, 2011; Rich, 2010) and educators alike (Nair, Patil, and Mertova, 2009; Hung \& Leon, 2005; Obi, 2004). Government officials fear the lack of desired manufacturing skills in the unskilled, managerial, and skilled labor markets, which includes college graduates, which continues to keep manufacturing jobs overseas and further weaken the economy. They feel that a retooling effort must begin at the high school, community college, and university levels for a comprehensive solution to the problem to occur (Olson, 2011). The need to address the skill shortage at all levels is at the heart of the American Manufacturing Efficiency and Retraining Investment Collaboration Achievement (AMERICA) Works Act supported by Congressman Joe Donnelly of Indiana and The Manufacturing Institute's Manufacturing Skills Certification System supported by President Obama (Olsen, 2011).

According to Raybould and Sheedy (2005), employers, in general, are looking for graduates with vital soft skills such as communication, action planning, and networking. According to Raybould and Sheedy (2005), employers, in general, are looking for graduates with vital soft skills, such as communication, action planning, and networking. These skills are typically introduced to students through their course work and improved during periods of work experience as co-op students or student interns. Today's employers are also placing a premium on graduates' writing skills, math skills, problem-solving skills, and attitude (Kay, 2011). Manufacturers have expanded the above requirements to include mechanical reasoning, trouble-shooting abilities, computer, initiative, and motivation skills, among others (Handler and Healey, 2009). According to Shah and Nair (2011), governments 
and industry often look to institutions of higher learning for help when the mismatch between skills needed and skills available occurs.

The imbalance between the current educational product and the needs of employers is nothing new. Studies in the early 1990's by Aaron Ball (1991) and William Brauer (1993) highlighted the gap between employer needs and existing manufacturing engineering curriculums. Over a decade later, researchers were exposing a global shortage of manufacturing skills despite attempts by colleges and universities to alter their curriculums and close the gap. Recent studies by experts in Australia (Shah and Nair, 2011), Great Britain (Raybould and Sheedy, 2005), South Africa (Kruss, 2004), and the U.S. (Handler and Healey, 2009) confirm its ever present existence. Some believe the gap exists because colleges and universities teach manufacturing systems from a global perspective, ignoring the differences within industries, geographic regions, and cultural influences (Obi, 2004). Others believe that the rapid pace of change in manufacturing has made it difficult for universities to retool at an acceptable pace (Nair, 2009; Chen, Jiang, and Hsu, 2005). Handler and Healey (2009) describe this new package of skills as a fundamental shift by manufactures in baseline requirements. As a result, graduates from American colleges and universities are ill-equipped to succeed in the manufacturing environment (Singleton, 2011; Nair, Patil, and Mertova, 2009; Handler and Healey, 2009).

\section{RESEARCH QUESTIONS}

This study examines the skill sets manufacturing employers seek when they hire recent college graduates for entry level management positions. The author seeks to answer the following research questions:

1. What skills should recent college graduates possess to succeed in today's manufacturing environment?

2. Do existing manufacturing curriculums equip graduates with the skill sets most sought after by current manufacturers?

\section{STUDY METHODOLOGY}

In an effort to determine the skills needed by graduates to succeed in manufacturing, 26 manufactures in North Central Ohio were asked to discuss the criteria they used for hiring recent college graduates to fill entry level management positions. Eighteen manufacturing companies agreed to participate. Participating companies represented an array of manufacturing disciplines (Table 1) and varied in size from large global to regional/national manufacturers. Survey data were collected through live onsite interviews or through telephone interviews. Participating companies made either their human resources manager responsible for hiring management personnel or their operations manager available for interviews. Companies electing to have the operations manager interviewed felt this individual was the source of the skill sets being sought during the job search process.

Table 1: Breakdown of Participating Manufacturers

\begin{tabular}{lcc}
\hline Type of Company & Customer Distribution & \# Interviewed \\
\cline { 2 - 3 } Electronics Component & Global & 3 \\
Automotive Supplier & Global & 3 \\
Plastics & Global & 2 \\
Medical Supplier & National & 1 \\
Pump & Global & 1 \\
Pump & National & 1 \\
Processed Food & Global & 1 \\
Processed Food & National/Regional & 1 \\
Home Repair & National & \\
\hline
\end{tabular}

\section{Delimitations}

The population of this study encompassed 18 companies located in the Midwest region of the United States. The Midwest is the home of a diverse population with a long manufacturing tradition. Thirteen of the 18 
participating companies $(72.2 \%)$ consider themselves global manufacturers. Given these facts, the author acknowledges the potential for the data to reflect a Midwestern bias toward the hiring practices in global manufacturers. Likewise, the manufacturing curriculums of the institutions reviewed were all located in the Midwest region of the U.S.

\section{RESEARCH RESULTS}

Analysis of survey data produced four themes regarding manufacturers' hiring practices and their satisfaction with the skill sets that colleges and universities provide college graduates. Of the 18 companies interviewed, all stated that recent college graduates do not possess the right skills to succeed in today's manufacturing environment. Survey participants stated that pieces of the skill sets they require are found in a variety of degree programs ranging from engineering, human resources, finance, and business management. According to survey participants, the top ten skills needed to succeed in manufacturing are listed in Table 2. All the managers interviewed stated that colleges and universities fail to understand the skills needed to succeed in today's manufacturing environment. As a result, hiring decisions often come down to choosing job candidates that require the least amount of costly in-house training. Manufacturers stated that college graduates possessing their five most frequently sought after skills are the most difficult to find. Interviewees were quick to point out that it is easy to hire a graduate with a degree in one particular field of study or specialty area, such as engineering. The problem is that they can no longer afford the luxury of hiring specialists. In today's lean economy, participants stated that employees must be able to assume multiple roles and perform a variety of tasks effectively.

Table 2: Top Ten Sought after Manufacturing Skills

\begin{tabular}{llcc}
\hline$\#$ & Skill & Frequency Requested & \% \\
2 & People Skills & 18 & 100.0 \\
3 & Work Experience & 16 & 88.9 \\
4 & Problem Solving & 14 & 77.8 \\
5 & Lean Principles & 14.8 & 66.7 \\
6 & Six Sigma Certification & 12 & 66.7 \\
7 & Mechanical Aptitude & 11 & 55.6 \\
8 & Multi-tasking Ability & 10 & 50.0 \\
9 & Self-Moct Management & 9 & 44.4 \\
10 & Results Orientation & 8 & 38.9 \\
\hline
\end{tabular}

\section{Theme 1 - People Skills}

Survey participants indicated that their most frequently sought after skill was actually a grouping of skills called "people skills". Table 3 lists the top employee management skills that manufacturers placed in this category. Relationship building was the most frequently requested people skill closely followed by the ability to be a team player. Survey precipitants indicated that many young graduates fail in the manufacturing environment because they are uncomfortable in team environments. They stated that graduates need more experience functioning within diverse teams and building relationships prior to entering the job market. The employers felt that team experiences afforded students the ability to hone the people skills they will need to succeed after graduation. The manufacturers stated that this rationale supports the premium they place on work experience in their job selection process. After two or three successful work sessions, as either a co-op student or intern, students should have acquired the people skills necessary to begin a manufacturing career.

Table 3: Most Frequently Requested People Skill

$\begin{array}{lc}\text { Skill } & \text { Frequency Requested } \\ \text { Relationship building } & 13 \\ \text { Team player } & 12 \\ \text { Ability to build trust } & 10 \\ \text { Good communicator } & 10 \\ \text { Leadership } & 9 \\ \text { Conflict Management } & 6\end{array}$

(C) 2012 The Clute Institute http://www.cluteinstitute.com/ 
The ability to build trust and to communicate effectively were skills that tied for third in the "people skill" category with leadership and conflict management completing the listing. As one manufacturer put it, "our priority is to hire employees who can handle any situation from managing a team, talking to the company president, to disarming a potentially violent situation on the shop floor". Survey participants stated that their inability to find these skills in recent graduates desiring manufacturing careers suggests that colleges and universities are not doing enough to prepare their students to succeed in the workplace.

\section{Theme 2- Current Curriculums are Inadequate}

To better understand the manufacturer's point of view, the manufacturing curriculums of 20 universities surrounding Ohio were examined. All 20 institutions contained a college of engineering. Fourteen of the 20 institutions prepared graduates for careers in manufacturing solely through the conveyance of engineering degrees. As expected, the primary focus of these curriculums was to provide students with the mechanical skills needed to function competently in their engineering discipline of choice. It is worth noting that mechanical competency ranked sixth on the list of most frequently sought after skills by the manufacturers surveyed. Only one of these institutions required students to take classes in human resource management, or "people skills", as part of their required engineering curriculum. In the remaining institutions, students were given the option to select these types of classes as electives.

Six institutions afforded students with the opportunity to peruse a manufacturing-related degree outside of their college of engineering. These schools granted degrees in manufacturing-related areas either through their schools of business or technology. Only three of these institutions required classes in "people skills" as part of their required curriculum. The remaining three institutions also provided elective options for students in these areas.

Survey participants acknowledged that many institutions provide students with co-op opportunities or internships as a way to gain valuable work experience prior to graduation. Often, these programs are optional to the student. The manufacturers surveyed state that although they applaud these efforts, universities should make work experiences a mandatory part of their curriculums. Employers state that when they screen job applicants, the existence of work experience in the student's desired career field is a definite qualifier. One employer stated that the existence of relevant work experience on a resume is the difference between receiving a face-to-face interview or a rejection letter. Further, manufacturers stated that they prefer graduates with three internship experiences but frequently settle for two work experiences when selecting job candidates. Students with one work experience on their resume receive consideration in the job selection process but are usually not selected for employment as a first option.

Manufacturers surveyed were also critical of graduates' problem-solving skills. They stated that too often recent graduates do not possess the logic, experience, and patience to effectively solve shop floor problems. All who were surveyed stated that colleges and universities could do more to prepare their graduates in this area. They suggested sending students out into the business community to help manufacturers solve real operations-based problems. These experiences would give students a real world appreciation of the problem-solving process and the complex relationships that exist between levels of the organization. All the interviewed manufacturers stated that the majority of recent graduates have difficulty working in teams and emphasized the importance of team interactions in the problem-solving process.

Survey participants stated that the above discussion is evidence that institutions of higher learning have not reacted fast enough to the changes in the manufacturing environment. All stated that colleges and universities should seek more interaction and input from the business community when designing curriculums. Without such interaction, many manufactures believe their job openings will continue to go unfilled.

\section{Theme 3 - High Emphasis on Logic and Math Skills}

In addition to people skills, an examination of Table 2 reveals that manufacturers are placing a high premium on mathematical skills and mechanical aptitude in their hiring processes. Problem-solving and six sigma skills - the third and fifth most frequently sought after skills - require specialized knowledge in logic, mathematics, 
and statistics. Success in these areas requires a complex understanding of the manufacturing processes, such as lean principles, and supply chain theory. Participants stated that, as employers, they are expecting graduates to come to them with such complex knowledge and to be ready to "hit the ground running".

Given the specialized nature of these skills, participants were asked if they believed that job candidates with engineering degrees were best suited to succeed in today's manufacturing environment. Five of the participating companies indicated that they preferred job candidates with engineering degrees when attempting to fill entry-level manufacturing jobs. These companies felt that an engineering degree ensured the level of technical competency employees needed to be successful. They also state that this background gives employers greater flexibility in the use of the individual and gives the employee a greater range of career options. It is also worth noting that four out of five (80\%) of the companies preferring an engineering background were large international manufacturers servicing the electronics, automotive, and specialized plastics industries with multiple global locations. Finally, these companies stated that the lack of required skills not possessed by engineers, specifically people skills, could be compensated for through in-house training or other site specialists.

The 13 companies not preferring engineering degrees were medium-size global, national or regional manufacturers. These companies stated that their organizations are very lean and require managers to assume many different roles. They stated that engineers often do not possess the people skills required to succeed in flexible organizations or work well in teams. As a result, this category of manufacturers did not feel that an engineering degree was necessary to succeed in manufacturing and they do not pursue such candidates when attempting to fill entry-level management positions. It is also worth noting that $38 \%$ of these same participants stated that they prefer to hire non-engineering degreed candidates because skilled business generalists command lower salaries than engineering specialists.

\section{Theme 4- Certifications Required}

The third theme to emerge from data was that manufactures believe that institutions of higher learning should do more to ensure that graduates earn professional certification in certain disciplines prior to graduation. The top three sought after certifications were problem-solving (77.7\%), six sigma techniques (66.7\%), and project management. Survey participants stated that in today's economy, every management position is important to the success of the organization. Professional certifications give them a better feel when assessing the actual skill level of job candidates. The guess work associated with knowing the competency of a particular institution or discipline is diminished. They stated that certification tells the employer the skill level of a particular job candidate regardless of the degree conferring institution.

\section{CONCLUSIONS AND RECOMMENDATIONS}

All surveyed manufacturers stated that they were not satisfied with the skills that recent college graduates bring to the workplace. Manufacturers, especially medium-size companies servicing global, national and regional markets, stated that they can no longer afford to hire employees as specialists in a given area. The need to compress organizations in reaction to current economic pressures has redefined their skill requirements. These manufacturers are seeking a combination of human resource skills, work experience, and technical competence bundled in a manner not addressed in most existing curriculums. These employers stated that employees must be prepared to assume a variety of tasks and roles - both technical and non-technical - as managerial resources diminish in organizations. Large global manufacturers were more willing to hire specialists but are also seeking a more diverse skill set among job candidates. As illustrated in Table 2, all manufactures are placing a high premium on people skills. People skills were the number one most sought after skill set among manufacturers surveyed. Many of the surveyed manufacturers stated that their human resources department shrank as they implemented lean strategies to survive. Seeking job candidates with accomplished people skills makes these reductions viable. In addition, manufacturers are expecting job applicants to possess a sophisticated set of technical skills. Problem-solving, lean skills, six sigma skills, and mechanical aptitude are skills that require technical competence in mathematics, statistics, and an array of manufacturing disciplines. 
Manufacturers are seeking a new type of job candidate. The majority of surveyed manufacturers stated that an engineering degree is not needed for success in their environments. Instead, they are seeking individuals who have organizational, business management, and technical skills - a request that encompasses a variety of unique disciplines and separate fields of study. To meet this demand, colleges and universities must retool their manufacturing curriculums. Traditional curriculums focused on technical competency, leaving the study of supporting disciplines to the discretion of students as electives or minor fields of study. Today, manufacturers have elevated such fields, particularly organization behavior and human resources management, to a level equal with technical competency. In addition, manufacturers are requesting that institutions stand behind their graduates by having them seek and acquire outside certifications before entering the job market.

\section{AUTHOR INFORMATION}

Dr. Daniel Sullivan is an Assistant Professor of Management/Entrepreneurship at Ashland University's Richard E. \& Sandra J. Dauch College of Business \& Economics. He holds an Economics degree from the University of Pittsburgh, an MBA from Indiana University of Pennsylvania, a J.D. from the University of Akron, and an Ed.D. in Organizational Leadership from Ashland University. He is an experienced business professional working 33 years in private industry. During this time, he held leadership positions in manufacturing, operations management, quality assurance, and labor negotiations. E-mail: dsulliv1@ashland.edu

\section{REFERENCES}

1. Ball, A.K. (1991). Master of Science in technology: Searching for a model. College Industry Education Conference Proceedings, 71-77.

2. Brauer, W.M. (1993). A needs assessment for a Master of Science degree in technology from Purdue University. (Doctoral dissertation, Purdue University, 1993). Dissertation International, 54, 3351.

3. Chen, C.K., Jiang, B.C., \& Hsu, K.Y. (2005, May). An empirical study of industrial engineering and management curriculum reform in fostering student's creativity. European Journal of Engineering Education, 30(2), Pg. 191-202.

4. Handler, C.A., \& Healy, M.C. (2009). Hiring manufacturing Staff in the 21st century: A fundamental shift in skills. TalentLens. Pearson Education, Inc. Retrieved August 28, 2011 from: http://www.google.com/\#hl=en\&cp=23\&gs id=2\&xhr=t\&q=Handler+\%26+Healey\%2C+2009)\&pf=p\&scl ient $=$ psy \&site $=\&$ source $=\mathrm{hp} \& \mathrm{pbx}=1 \& \mathrm{oq}=$ Handler $+\% 26+$ Healey,+2009$) \& \mathrm{aq}=\mathrm{f} \& \mathrm{aqi}=\& \mathrm{aql}=\& \mathrm{gs} \_\mathrm{sm}=\& \mathrm{gs}$ upl=\&bav=on.2,or.r_gc.r_pw.\&fp=cf799297008d2d18\&biw=1280\&bih=617

5. Hung, W.N., \& Leon, V.J. (2005). Manufacturing education and research at Texas A\&M University: Responding to global trends. Journal of Manufacturing Systems, 24(3), Pg. 153-161.

6. Kay, A. (2001, 30 May). What employers want: 5 more skills to cultivate. USA Today. Retrieved September 5, 2011 from: http://www.usatoday.com/money/jobcenter/workplace/kay/2011-05-30-skillsemployers-want-part-ii_N.htm

7. Nair, C.S., Patil, A., \& Mertova, P. (2009. May). Re-engineering graduate skills - A case study. European Journal of Engineering Education, 34(2), Pg. 131-139.

8. Obi, S. C. (2004, Spring). Silicon Calley's processing needs versus San Jose State University's manufacturing systems processing component: Implications for industrial technology. The Journal for Technology Studies, Pg 104-7.

9. Olsen, E.G. (2011, June). How to train U.S. workers back into manufacturing jobs. Fortune. Retrieved August 28, 2011 from; http://management.fortune.cnn.com/2011/06/29/how-to-train-u-s-workers-backinto-manufacturing-jobs/

10. Rich, M. (2010, 1 July). Factory jobs return, but employers find skill shortage. The New York Times. Retrieved August 27, 2011 from: http://www.nytimes.com/2010/07/02/business/economy/02manufacturing.html

11. Roadmap to Education Reform for Manufacturing, National Manufacturing Talent Development Roundtable, December 1, 2010. The Manufacturing Institute.

12. Raybould, J., \& Sheedy, V. (2005). Are graduates equipped with the right skills in the employability stakes? Industrial and Commercial Training, 37(5), p. 259-263. 
13. Shah, M., \& Nair, C.S. (2011). Employer satisfaction in university graduates: Key capabilities in early career graduates. Teaching and Learning Forum. Retrieved September 3, 2011 from http://otl.curtin.edu.au/tlf/tlf2011/refereed/shah.html

14. Singleton, D. (2011, 29 April). Manufacturers are hiring again; What skills are they looking for. Software Advice. Retrieved September 4, 2011 from:

http://www.softwareadvice.com/articles/manufacturing/manufacturers-skills-in-demand-1042911/ 
\begin{tabular}{ll} 
International Journal of Management \& Information Systems - Third Quarter $2012 \quad$ Volume 16, Number 3 \\
\hline
\end{tabular}

NOTES 